\title{
ASSESSMENT OF HUMAN-WILDLIFE CONFLICT AND ITS IMPLICATION FOR CONSERVATIONATSUNDARPUR, UDAYAPUR, EASTERN NEPAL
}

\author{
Chandramani Aryal $^{1^{*}}$, Manoj Pokharel ${ }^{1}$ \\ ${ }^{1}$ Department of Environmental Science, Tri-Chandra Multiple Campus, Kathmandu, TU \\ *Corresponding author
}

\begin{abstract}
This study was carried out to document the prevailing situation of humanwildlife conflict in Sundarpur of Udayapur district, Nepal where significant numbers of sloth bear along with other troublesome wildlife species occur. Data about conflict and people's perception towards wildlife conservation was collected using household surveys supplemented by key informant interviews and direct observation method. Monkeys (93\%) and elephants (86\%) were found to be major animals involved in conflict mostly resulting into crop raiding, which was the major form of conflict as reported by (95\%) of respondents. Livestock depredation cases were mostly by common leopard (84\%) and sloth bear was involved in majority of human attack cases (90\%). According to respondents, the trend of conflict was found to be increasing for elephants (63\%) and monkeys (73\%) while it was found to be decreasing for sloth bear (64\%), wild boar (85\%), and leopard (46\%), where people believed natural attraction of wildlife towards crops/livestock to be the major driving factor of conflict. Despite the prevalence of conflict most of the respondents showed positive attitude towards wildlife conservation in Sundarpur. This implies a better future for wildlife conservation in this area if the issues associated with human-wildlife conflict are addressed effectively.
\end{abstract}

Keywords: crop raiding - elephant - human injury - livestock depredation - monkey property damage - sloth bear. 


\section{INTRODUCTION}

Increased use of wildlife habitat by humans is continuously creating pressure on wildlife resulting in frequent interactions between the two (Barua, Bhagwat \& Jadhav 2013). Such interactions are often negative and present a complex challenge for successful conservation of biodiversity throughout the world (Treves \& Karanth 2003, Acharya, et al. 2016). This issue, commonly known as human-wildlife conflict (HWC) has several other consequences that not only threatens the survival of wildlife species, but also creates severe socio-economic tension among people, which may have a long term effect on human well being (Shrestha 2007, Dickman 2010, Barua, Bhagwat \& Jadhav 2013). The situation is more prevalent in developing regions of the world, where competition for natural resources between humans and wildlife is greatest (Barua, Bhagwat, \& Jadhav 2013, Gemeda \& Meles 2018). Nepal where significant percentage of land is designated as protected areas, HWC is widespread throughout these areas (MoFC 2014, Awasthi \& Singh 2015, Sherchan \& Bhandari 2017), and even the non-protected areas are not exceptional to this scenario (Shrestha 2007), as significant population of wildlife fall outside of protected areas (Bhuju, et al. 2007).

Most of HWC cases in Nepal have been documented from Tarai region (Heinen 1993, Bhattarai \& Fischer 2014) probably because the region shelters highest population of both humans and wildlife species (Shrestha 2007). Increased intensity of conflict in eastern Tarai region, where the wildlife habitat is largely unprotected has also been reported (Shrestha 2007, Neupane, Johnson \& Risch 2014). Similarly, the cases of HWC are found to be dominated by Elephant (Elephas maximus)and Common Leopard (Pantherapardus) throughout their range in Nepal with worsening situation outside protected areas (Acharya, et al. 2016).Sundarpur area of Udayapur district which lies in eastern Tarai region of Nepal is known to hold important sloth bear population of Nepal (Jnawali, et al. 2011), as well as shelters other 'troublesome' wildlife species including elephants and leopards (Khadka, Acharya \& Chaudhary 1994, Chhetry \& Pal 2010). Occurrence of these animals outside the boundary of any protected area has a strong possibility of having some forms of conflict with humans. Despite of this vulnerability to HWC, studies documenting the conflict do not occur 
from this region, creating research gap in this field. Thus, this study was carried out to provide baseline information about the situation of HWC in the area. The specific aims of this study were to (1) document major forms of HWC and the troublesome animals in the study area, (2) assess the trend and driving forces of HWC according to the perception of local people, and (3) provide insight into the attitude of local people towards conservation of threatened wildlife species which are involved in conflict.

\section{METHODS}

\section{Study Area}

The study was carried out in Sundarpur of Chaudandigadhi Municipality, which lies in Udayapur district of eastern Nepal (Figure 1). It is one of four urban municipalities of Udayapur district with an estimated total population of 57,360. It covers an area of $283.78 \mathrm{~km}^{2}$ and contains total of 10 wards. Sundarpur lies in ward number 5 of the municipality with a total population of 5673 individuals in around 1372 households (Chaudandigadhi Municipality 2019). The area lies nearly 90 Km west (Road distance) from the Biratnagar and nearly $45 \mathrm{Km}$ (Road distance) west from the Headquarter of Koshi Tappu Wildlife Reserve. Climate here is of tropical monsoon type, characterized by three distinct seasons, summer (February-May), monsoon (June-September), and winter (October-January). Annual maximum temperature of the region is around $41^{\circ} \mathrm{C}$ with annual minimum temperature around $16^{\circ} \mathrm{C}$ (Chhetry \& Pal 2010, Thapa 2015).Vegetation of this area is dominated by Shorearobusta, while Dalbergiasisso, Acacia catechu, and Bombaxceiba are some other common tree species found in the region. Major faunas of this area are Spotted deer (Axis axis), Wild boar (Susscrofa), Pangolin (Manis spp.), Rhesus macaque (Macacamulatta), Common leopard (Pantherapardus), Gaur (Bosgaurus), Asiatic elephant (Elephas maximus), along with Sloth bear (Melursusursinus), (Heinen 1993, Khadka, Acharya \& Chaudhary 1994, Chhetry \& Pal 2010). 


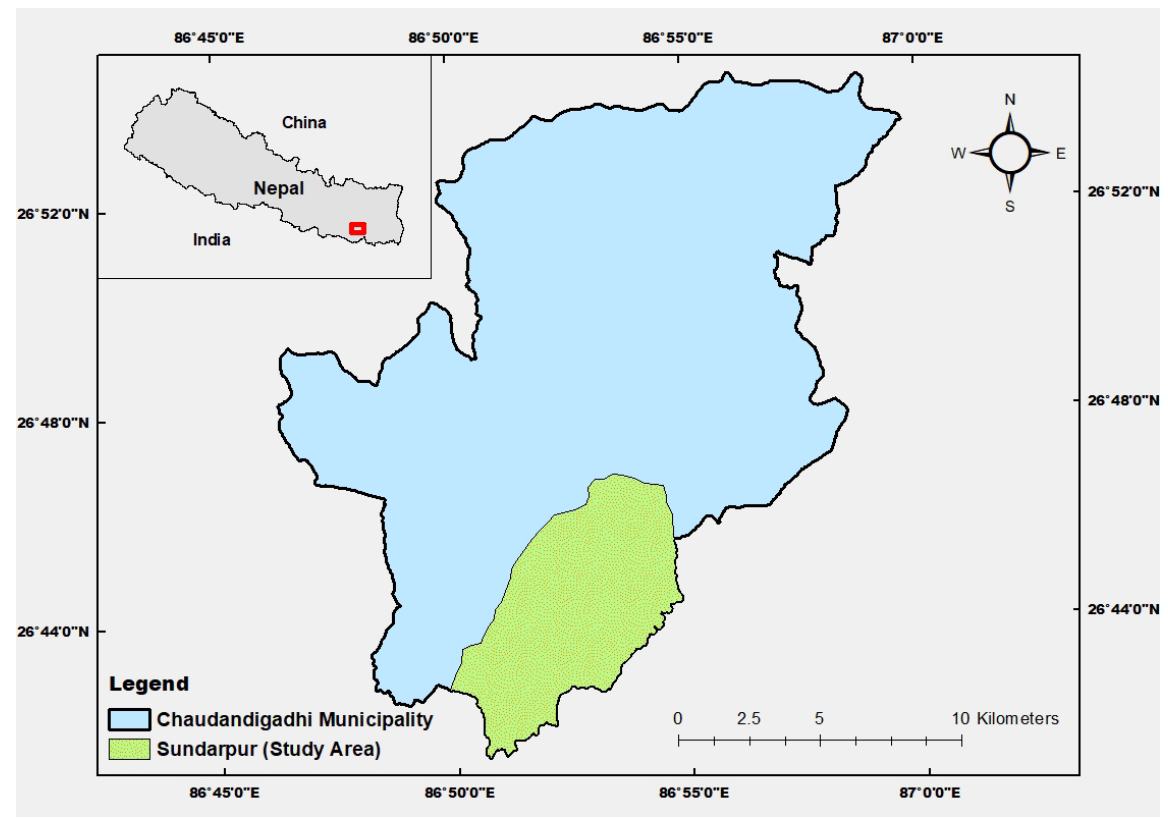

Figure 1: Map of study area

\section{Study unit}

For the questionnaire survey, each household were taken as the study unit. Thus, the head of the house or the senior persons were interviewed to collect the information. For key informant interview (KII) each key informant were considered as the study unit.

\section{Survey design and data collection}

Hundred households of Sundarpur which represented around 7\% of total $(\mathrm{n}=1372)$ households were surveyed during October 2018 (Grosh \& Glewwe 2000). Participating households were chosen based on systematic sampling method (Parker \& Thapa 2011), where every fourth household was surveyed after randomly selecting the first one. Household survey was supplemented by Key Informant Interviews (KII) $(n=5)$ with community and sector forest officials, and direct observation method (Sherchan \& Bhandari 2017), for enhancing the validity of data obtained. A semi-structured set of questionnaire was used for collection of data which consisted questions of socio-economic background of respondent, experiences of crop and livestock depredation, human injury, death, and property damaged by 
wildlife along with mitigation measures adopted for minimizing the conflict. There were also questions related to driving forces and trend of conflict along with people's attitude towards conservation of threatened species that are involved in the conflict. A different set of questionnaire was administered to Key Informants which mainly contained questions related to compensation schemes and mitigation measures adopted to minimize the intensity of conflict as well as the role played by them in conservation of wildlife present in the area.

\section{Data analysis}

The data obtained was analyzed using both quantitative and qualitative measures. M.S. excel and Statistical software JASP ver. 0.9.2 (JASP team 2018) was used for analysis, where most of the data was analyzed using descriptive statistics (mean, standard deviation, and percentage). The research hypothesis was "the perception of the local people about the species conservation are the function of their gender". To analyze the relationship between attitude of local people towards wildlife conservation and their gender, $\chi^{2}$ test of independence was used.

\section{RESULTS}

\section{Socio-economic characteristics}

Out of the total $(n=100)$ respondents that were interviewed, $(30 \%)$ were female and $(70 \%)$ were male. Average family size of the respondents was $5.25(\mathrm{SD}=1.75)$ persons. The eldest and youngest respondents were 87 and 17 years of age respectively and the mean age was $45.68(\mathrm{SD}=16.57)$. Most of the respondents i.e. $(90 \%)$ were farmer, while (4\%) were labor, (3\%) were businessman, $(2 \%)$ were teacher, and (1\%) were carpenter. People not having farming as major occupation were also involved in farming as 100\% of the respondents owned their own farmland. Rice, maize, wheat, millet, and vegetables were most commonly cultivated crops with cow, buffalo, ox, and goat as major livestock hold by people of the area.

\section{Human-wildlife conflict}

The study revealed that $97 \%$ of the sampled households were having problems of one or another form with the wild animals. Monkeys $(93 \%)$ and elephants $(86 \%)$ were major animals involved in the conflict 
followed by others (Figure 2). Significant portion of respondents (95\%) believed crop depredation to be the major form of conflict they have been facing. However, other consequences of conflict - livestock depredation $(23 \%)$, property damage $(22 \%)$, and human injury (10\%) were also recorded during the study.

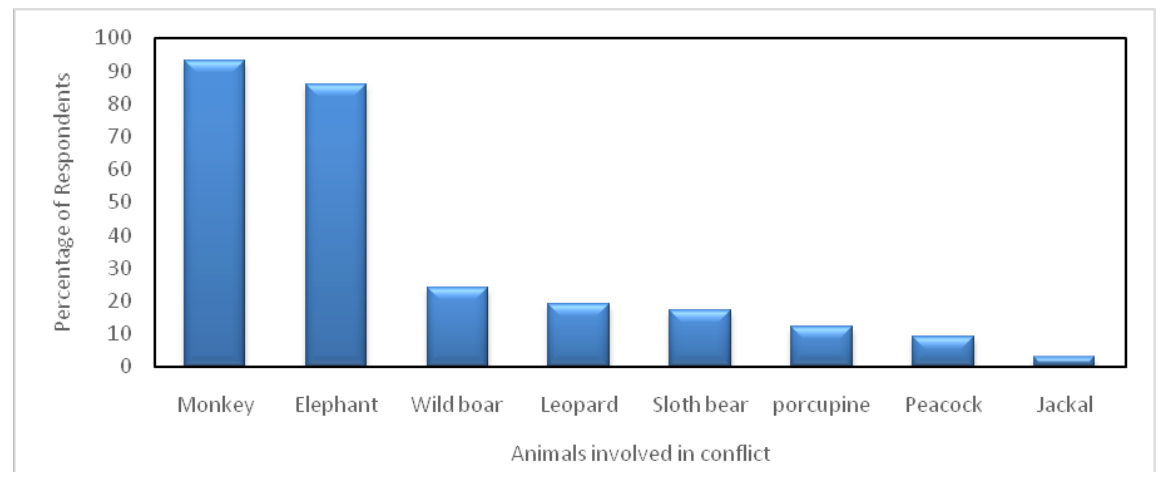

Figure 2: Major animals involved in human-wildlife conflict in Sundarpur

Crop depredation in the area was primarily due to monkeys, elephants, and wild boars. Thus, they were only taken into account for further analysis. Monkeys were reported for (43\%) of crop raiding incidents, which was followed by elephants (38\%), and wild boar (19\%). The degree of crop damage varied among different crop species cultivated in the area. Paddy (32\%) was the most commonly raided crop along with maize $(21 \%)$, wheat $(17 \%)$, millet $(10 \%)$, and others $(20 \%)$. Elephants mainly preferred rice and wheat, as $(50 \%)$ of rice and $(59 \%)$ of wheat damage reported was due to elephants only, while maize was mostly preferred by monkeys (figure 3).Elephant was also responsible for damaging property $(n=22)$, accounted for the time period of five years. House (41\%) was most commonly damaged property which was followed by storehouse of grains (36\%), and kitchen (23\%).Majority of respondents said conflict is increasing with monkeys $(73 \%)$ and elephants $(63 \%)$ while it is decreasing with wild boar (85\%). People believed natural attraction to crops of elephants (40\%), and monkeys (38\%) to be a major driving factor of conflict followed by increased population of elephants (32\%) and monkeys (34\%). 


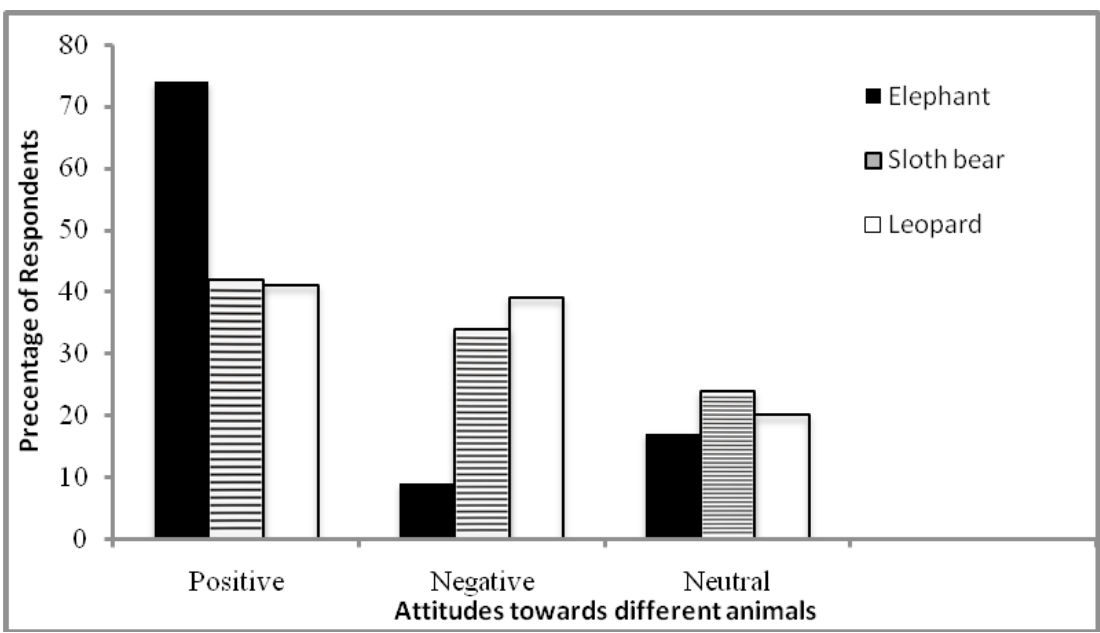

Figure 3: Major crops and the degree of damage caused to them by wild animals in Sundarpur

Cases of livestock depredation $(n=25)$ were primarily by common leopard $(84 \%)$ and than by jackal $(16 \%)$, where goat $(68 \%)$ was most commonly raided livestock followed by cow calf $(20 \%)$, poultry $(8 \%)$ and adult cow (4\%).

Leopard mostly killed goats and accounted for (88\%) of the total goat kills. Remaining of goat depredation $(n=2)$ was reported to be by jackal. After goat, cow calf $(n=5)$ was found to be the preferred target of leopard, and one only instance of depredation of an adult cow was attributed to it. Jackal was also found to be responsible for the poultry raiding cases $(n=2)$ in the sampling site. Livestock depredation due to leopard mostly occurred in forest $(n=18)$ but had also occurred inside settlement $(n=2)$ and near to settlement $(n=1)$. Natural attraction towards livestock was thought to be major driving force of conflict with leopard by most of the respondents (43\%) with majority of them (46\%) also believing that conflict with leopard is decreasing these days. In addition to livestock depredation, one incident of human injury by leopard was also accounted during the study; however the case was mostly dominated by sloth bear and accounted for $(n=9)$ incidents of human injury in ten years (2008-2018). Majority of these attacks $(n=8)$ took place in forest when people had visited for collection of fodder, firewood and for grazing livestock. Only one attack occurred in the riverside close to settlement when the person was defecating. The number of attacks varied with years where two people each were injured in 
the year 2008, 2011, and 2012 and one people each injured in 2010, 2013, and 2015. Victims of sloth bear attack mostly belonged to age group 37$46(n=5)$, followed by age group 47-56 $(n=3)$, and 57-66 $(n=1)$. Attacks were common during afternoon (56\%), than in morning (33\%) and evening $(11 \%)$, where a large percentage of victims $(78 \%)$ were male and only $(22 \%)$ were female. Bears involved in attack were often single (67\%), which was followed by one mother bear with one cub (22\%), and mother bear with two cubs $(11 \%)$. A large percentage of respondents $(64 \%)$ believed that conflict with sloth bear is decreasing, even though majority of them (48\%) believed that population of sloth bear is increasing.

\section{People's attitude towards wildlife conservation}

Majority of respondents showed positive attitude for conservation of all the three species that were considered for this purpose. Among all species, conservation of elephant was favored by a large majority (74\%) compared to sloth bear (42\%) and leopard (41\%) (Figure 4). Analyzing the relationship between respondents gender and their attitude towards conservation, it was found that male $(84.2 \%)$ were more positive for elephant conservation than female $(50 \%) \quad\left(\chi^{2}=12.86, \mathrm{df}=3, \mathrm{p}=0.005\right)$. Likewise, conservation of leopard was also most favored by male (42.9\%) than that of female $(36.7 \%)\left(\chi^{2}=9.333, \mathrm{df}=3, \mathrm{p}=0.025\right)$. In case of sloth bear, although male $(44.3 \%)$ seem more positive for conservation compared to female $(36.7 \%)$, this difference was not found to be significant $\left(\chi^{2}=2.317\right.$, $\mathrm{df}=4, \mathrm{p}=0.678)$.

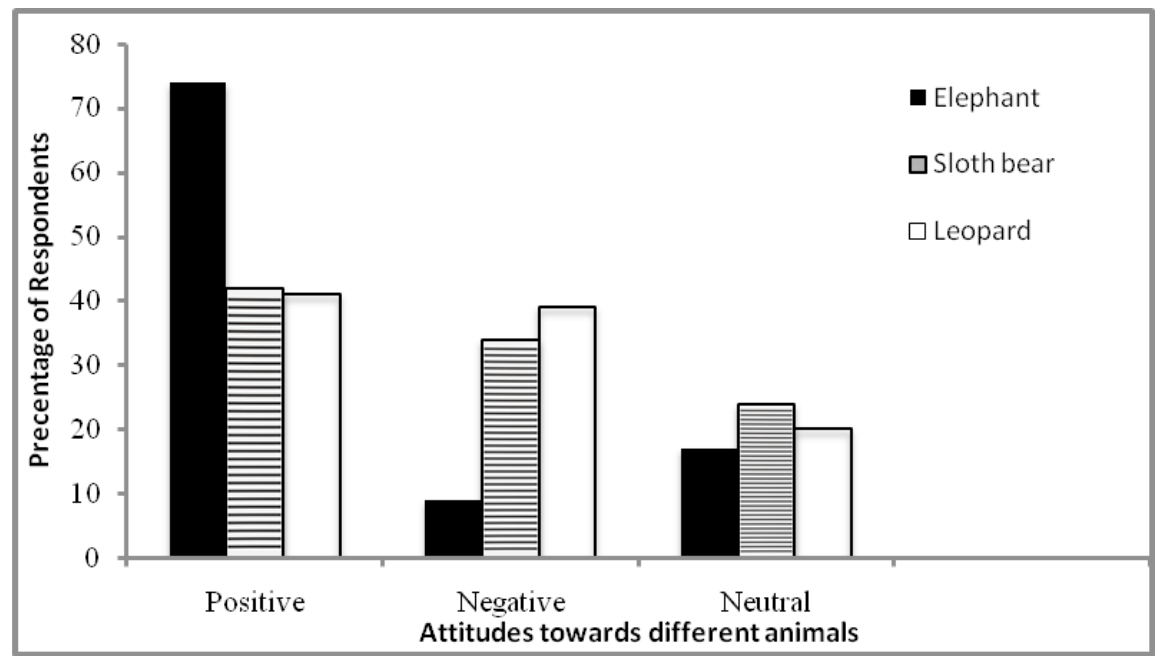

Figure 4: People's attitude towards wildlife conservation 


\section{DISCUSSIONS}

\section{Human-wildlife conflict}

Our results indicate that, with majority of residents involved in farming the people of Sundarpur have largely been affected by the consequences of HWC. This has surely resulted into decreased livelihood opportunities for local people, which is the case in many of the developing countries (Gemeda \& Meles 2018). Crop raiding by wild animals was by far the most serious problem here, showing similarity with other studies (Karanth, Gopalaswamy, DeFries \& Ballal 2012, Gemeda \& Meles 2018), where elephants were responsible for large scale damage of crops and monkeys were most frequent raiders followed by wild boar. Similar behavior of these animals has been reported from many parts of their occurrence range (Fernando, Wikramanayake, Weerakoon, Jayasingh, Gunawardene, \& Janaka 2005, Hill \& Webber 2010, Pandey, Shaner \& Sharma 2015). From our study, it can also be inferred that crops like paddy, maize, and wheat are most likely to be damaged by wildlife (Studsrod \& Wegge 1995), and elephants mostly preferred paddy and wheat (Shrestha 2007, Thapa 2010). Rich nutrients availability in these crops is the foremost reason behind the attraction of wild animals especially mega herbivores like elephants towards them (Hoare 1999). Locals also believed that after the crops are harvested elephants start visiting human settlements looking for the stored crop and cause damage to their property. Similarly, the declining trend of conflict with wild boar in Sundarpur differed from other studies (Thapa 2010, Pandey, Shaner \& Sharma 2015). The reason might be large scale hunting of wild boar in the past as revealed by few respondents, which might have regulated its population to this extent. Hunting pressure was reported to be high in the Triyuga forest including Sundarpur area (Aryal 2016). Pandey, Shaner \& Sharma (2015) has also mentioned regulated hunting of wild boar to be effective for management of its population size in order to reduce the conflict.

Leopard was the principal livestock predator of the area, which shows analogy with studies from different parts of the world (Constant, Bell, \& Hill 2015, Mir, et al. 2015). As most of the attacks have been reported to occur in forest, use of effective herding practices along with careful selection of grazing zones by the local people (Inskip \& Zimmermann 2009) can decrease the incidents of livestock depredation by leopard. Preference of goats and cow calves by leopard has been attributed 
to their moderate size making easy for leopard to drag the prey to safe place after killing (Bibi, et al. 2013). Thus, livestock of moderate sizes are more vulnerable and herders should pay extra attention while herding them near or within the leopard habitat. Even though leopards are well known for causing human casualties throughout their range in Nepal (Acharya, et al. 2016), the intensity in Sundarpur was found to be low and sloth bear was responsible for most of such cases. Unlike leopard, attacks by sloth bear have basically been accepted to be defensive in nature rather than predatory and mostly occur when human and bear suddenly encounter in areas having obstructed visibility (Yoganand, Rice \& Johnsingh 2005). So, avoiding habitats that have thick vegetation or anything that can obstruct visibility can minimize encounter rates between human and sloth bear. Despite the fact that sloth bears are mostly nocturnal or crepuscular (Bargali, Akhtar \& Chauhan 2005, Yoganand, Rice, \& Johnsingh 2005) our results show that sloth bears could be active during daylight hours around Sundarpur as majority of attacks have occurred in that time. However, it would simply be unwise to make such conclusions without further research on ecology and behavior of sloth bear in this area.The perceived decrement in sloth bear conflict regardless of their increased population as reported in Sundarpur occurs as contradiction to other studies (Yoganand, Rice \& Johnsingh 2005, Dharaiya, Bargali \& Sharp 2016). However, frequency of conflict with sloth bear has been related with the degree of use of forested areas by people where sloth bear occur and is not largely associated with bear abundance(Yoganand, et al. 2006). Thus, as mentioned by key informants, increase in forest area, ban on hunting, and regular patrolling of forest by forest officials after commencement of community forestry program in the area can be related with reduced human activities in forest resulting in reduced conflict with sloth bear.

\section{Compensation and mitigation measures}

Conflict with wildlife was prevalent in Sundarpur, but use of appropriate mitigation measures was found to be lacking. Crop guarding, using scarecrows in crop field, lighting fire and firecrackers, and group shouting were the measures adopted by local people to minimize conflict. Even though such methods have been utilized in other parts of country (Studsrod \& Wegge 1995, Thapa 2010, Neupane, Johnson \& Risch 2014), it is essential to test the effectiveness of these methods and introduce new effective measures in Sundarpur area to minimize intensity of HWC. Compensation for the damage caused by wildlife is another means to mitigate 
HWC (Karanth, Gopalaswamy, DeFries \& Ballal 2012). Community and sector forest officials of Sundarpur reported to provide timber and firewood as compensation for most wildlife damage and cash was known to be provided only for human casualties. Majority of respondents were unsatisfied with this existing compensation scheme indicating a need for implementing more robust methods of compensation as mentioned in other studies (Studsrod \& Wegge 1995, Karanth, et al. 2012).

\section{People's attitude towards wildlife conservation}

Attitude of people towards conservation greatly influences the conservation success of particular species (Nepal \& Weber 1995, Barua, Bhagwat \& Jadhav 2013). In our case majority of people were positive for wildlife conservation (Karanth \& Nepal 2012) with elephants gaining widespread support. Hindu people worship elephants as Lord Ganesh. This religious sentiment is believed to be largely responsible for the high degree of tolerance to elephants (Shrestha 2007). This greatly supports the finding that social factors play a major role in determining the people's attitude towards wildlife (Dickman 2010). Even in small number, people who opposed conservation can seriously hinder conservation of the wildlife species by getting involved in different illegal activities as well as by influencing other people to develop similar attitude (Mir, et al. 2015). Thus, it is seen essential to establish community based conflict management strategies along with conservation education programs (Kabir, et al. 2013, Can, et al. 2014), in Sundarpur which may foster more positive attitude among local people towards wildlife conservation. Our results also indicated significant role played by gender regarding attitude towards wildlfe, with males more positive than females (Bhattarai \& Fischer 2014, Mir, et al. 2015). The reason behind this might be the fear associated with wild animals. Males who are mostly involved in outdoor activities might have frequent interactions with wild animals which might have reduced their fear towards them (Røskafta, et al. 2003). However, the case might be opposite among women, who largely spend their time in indoor activities.

\section{Way forward}

In the face of rapidly declining wildlife populations it has never been so urgent to address the emerging problems of conservation. Conservation interventions should not only be focused around protected areas but also in areas where the habitat remains unprotected. This study have explored the cases of human wildlife conflict in the area and have 
established a baseline. Temporal and spatial dynamism of human wildlife conflict should be monitored regularly in the area. Additionally, mapping the spatiotemporal dimension of human wildlife conflict in the area could be helpful to orient conservation intervention. Additionally, holistic conflict management plans to address all forms of problems associated with human and wildlife conflicts are essential for effective outcomes are essential.

\section{CONCLUSIONS}

This study depicts the conservation challenge from unprotected areas of Sundarpur of eastern Nepal where the prevalence of HWC has caused detrimental effect to both humans and wildlife of this region. Conflict in the forms of livestock depredation, property damage, and human injury were less intense than crop depredation mainly caused by the monkeys and elephants. Despite all, majority of the respondents have shown positive attitude towards wildlife conservation,making us optimistic about the future of biodiversity conservation in this area. Nevertheless, it is highly essential to start addressing the issues associated with HWC by recognizing local community as key stakeholder of the intervention.

\section{ACKNOWLEDGEMENTS}

We would like to acknowledge Asst. Prof. Mr. Kishor Kumar Maharjan, Head of Department of Environmental Science, Tri-Chandra Multiple campus for his assistance in different phase of this research work. We are also grateful toAsst. Prof. Sanu Raja Maharjan and Mrs. Bina Ghimire, Tri-Chandra Multiple Campus for their valuable suggestion. We would like to express our sincere gratitude to all the faculty members of the Department of Environmental Science of Tri-Chandra Multiple Campus and the people of Sundarpur for their kind support leading to successful completion of this work. Besides, we would like to thank anonymous reviewer for valuable comments and suggestions to make improvement on the initial manuscript.

\section{WORK CITED}

Acharya, K. P., Paudel, P. K., Neupane, P. R., \& Köhl, M. (2016). Humanwildlife conflicts in Nepal: Patterns of human fatalities and injuries caused by large mammals. PLoS ONE, 11(9), 1-18.

Aryal, C., (2016). Evaluation of suitability of Triyuga forest of Eastern Nepal as potential Tiger (Panthera tigris tigris, Linneus, 1758) habitat. M.Sc. Dissertation, Tribhuvan University, Nepal. 
Awasthi, B., \& Singh, N. B. (2015). Status of human-wildlife conflict and assessment of crop damage by wild animals in Gaurishankar Conservation Area, Nepal. Journal of Institute of Science and Technology, 20(1): 107-111.

Bargali, H., Akhtar, N., \& Chauhan, N. (2005). Characteristics of sloth bear attacks and human casualties in North Bilaspur Forest Division, Chhattisgarh, India. Ursus, 16(2): 263-267.

Barua, M., Bhagwat, S. A., \& Jadhav, S. (2013). The hidden dimensions of human-wildlife conflict: Health impacts, opportunity and transaction costs. Biological Conservation, 157: 309-316.

Bhattarai, B. R., \& Fischer, K. (2014). Human-tiger Panthera tigris conflict and its perception in Bardia National Park, Nepal. Oryx, 48(4): 522-528.

Bhuju, U. R., Shakya, P. R., Basnet, T. B., \& Shrestha, S. (2007). Nepal biodiversity resource book: Protected areas, Ramsar sites, and world heritage sites. International Centre for Integrated Mountain Development (ICIMOD) and Ministry of Environment, Science and Technology (MOEST), Government of Nepal (GoN). Kathmandu, Nepal.

Bibi, S. S., Minhas, R. A., Awan, M. S., Ali, U., \& Dar, N. I. (2013). Study of ethno-carnivore relationship in Dhirkot, Azad Jammu and Kashmir (Pakistan). The Journal of Animal \& Plant Sciences, 23 (3): 854-859.

Can, O. E., D’Cruze, N., Garshelis, D. L., Macdonald, W. D., \& Beecham, J. (2014). Resolving human-bear conflict: a global survey of countries. Conservation Letters, 7(6): 501-513.

Chaudandigadhi Municipality. (2019). Chaudandigadhi municipality, office of prime executive, province No. 1, Government of Nepal. http:// chaudandigadhimun.gov.np (Accessed: 05.06.2019).

Chhetry, D. T., \& Pal, J. (2010). Diversity of mammals in and around of Koshi Tappu Wildlife Reserve. Our Nature, 8: 254-257.

Constant, N. L., Bell, S., \& Hill, R. A. (2015). The impacts, characterisation and managementof human-leopard conflict in a multi-use land system in South Africa. Biodiversity Conservation, 24(12): 29672989.

Dharaiya, N., Bargali, H., \& Sharp, T. (2016). Melursus ursinus. The IUCN Red List of Threatened Species 2016. 
Dickman, A. (2010). Complexities of conflict: the importance of considering social factors for effectively resolving human-wildlife conflict. Animal Conservation, 13: 458-466.

Fernando, P., Wikramanayake, E., Weerakoon, D., Jayasingh, L., Gunawardene, M., \& Janaka, H. (2005). Perceptions and patterns of human-elephant conflict in old and new settlements in Sri Lanka: Insights for mitigation and management. Biodiversity and Conservation, 14(10): 2465-2481.

Gemeda, D., \& Meles, S. (2018). Impacts of human-wildlife conflict in developing countries. Journal of Applied Sciences and Environmental Management, 22(8): 1233-1238.

Grosh, M., \& Glewwe, P. (eds.). (2000). Designing household survey questionnaires for developing countries. Washington, D.C. 20433, U.S.A.: World Bank Publications.

Heinen, J. T. (1993). Park-people relations in Kosi Tappu Wildlife Reserve, Nepal: A socio-economic analysis. Environmental Conservation, 20(1): 25-34.

Hill, C. M., \& Webber, A. D. (2010). Perceptions of nonhuman primates in human-wildlife conflict scenarios. American Journal of Primatology, 72: 919-924.

Hoare, R. (1999). Determinants of human-elephant conflict in a land-use mosaic. Journal of Applied Ecology, 36: 689-700.

Inskip, C., \& Zimmermann, A. (2009). Human-felid conflict: a review of patterns and priorities worldwide. Oryx, 43(1): 18-34.

JASP team. (2018). JASP, 0.9.2. https://jasp-stats.org (Accessed: 07.06.2019).

Jnawali, S. R., Baral, H. S., Lee, S., Subedi, N., Acharya, K. P., Upadhyay, G., et al. (2011). The status of Nepal's Mammals : The National Red List Series. Department of National Parks and Wildlife Conservation. Kathmandu, Nepal.

Kabir, M., Ghoddousi, A., Awan, M. S., \& Awan, M. N. (2013). Assessment of human-leopard conflict in Machiara National Park, Azad Jammu and Kashmir, Pakistan. European Journal of Wildlife Research, 60 (2): 291-296. 
Karanth, K. K., \& Nepal, S. K. (2012). Local residents perception of benefits and losses from protected areas in India and Nepal. Environmental Management, 49: 372-386.

Karanth, K. K., Gopalaswamy, A. M., DeFries, R., \& Ballal, N. (2012). Assessing patterns of human-wildlife conflicts and compensation around a central Indian protected area. PLoS ONE, 7(12): 1-13.

Khadka, N., Acharya, P., \& Chaudhary, C. (1994). Ecology and conservation of Bos gaurus in Belaka forest of Udayapur district, Nepal. Banko Janakari, 7(2): 39-42.

Mir, Z. R., Noor, A., Habib, B., \& Veeraswami, G. G. (2015). Attitudes of local people toward wildlife conservation: A case study from the Kashmir Valley. Mountain Research and Development, 35(4): 392-400.

MoFC. (2014). Nepal fifth national report to convention on biological diversity. Kathmandu: Government of Nepal, Ministry of Forests and Soil Conservation.

Nepal, S. K., \& Weber, K. E. (1995). The quandary of local People-Park relations in Nepal's Royal Chitwan National Park. Environmental Management, 19(6): 853-866.

Neupane, D., Johnson, R. L., \& Risch, T. S. (2014). Temporal and spatial patterns of human-elephant conflict in Nepal. International Elephant \& Rhino Conservation \& Research Symposium Proceedings. Pittsburgh Zoo \& PPG Aquarium. pp. 1-11.

Pandey, P., Shaner, P.-J. L., \& Sharma, H. P. (2015). The wild boar as a driver of human-wildlife conflict in the protected park lands of Nepal. European Journal of Wildlife Research, 62(1), 103-108.

Parker, P., \& Thapa, B. (2011). Natural resource dependency and decentralized conservation within Kanchenjunga conservation area project, Nepal. Environmental Management, 49(12): 435-444.

Røskafta, E., Bjerke, T., Kaltenborn, B., Linnell, J. D., \& Andersen, R. (2003). Patterns of self-reported fear towards large carnivores among the Norwegian public. Evolution and Human Behavior, 24 (3): 184-198.

Sherchan, R., \& Bhandari, A. (2017). Status and trends of humanwildlife conflict: A case study of Lelep and Yamphudin region, 
Kanchenjunga Conservation Area, Taplejung, Nepal. Conservation Science, 5(1): 19-25.

Shrestha, R. (2007). A case study on human-wildlife conflict in Nepal (with particular reference to human-elephant conflict in eastern and western Terai regions). Report submitted to WWF International, WWF Nepal, Kathmandu.

Studsrod, J. E., \& Wegge, P. (1995). Park-people relationships: The case of damage caused by park animals around the Royal Bardia National Park, Nepal. Environmental Conservation, 22(2): 133-142.

Thapa, S. (2010). Effectiveness of crop protection methods against wildlife damage: A case study of two villages at Bardia National Park, Nepal. Crop Protection, 29(11): 1297-1304.

Thapa, S. (2015). Living with villagers for bat conservation at Triyuga Municipality, Udayapur, Nepal. Zoo's Print, 30(9): 14-17.

Treves, A., \& Karanth, K. U. (2003). Human-carnivore conflict and perspectives on carnivore management worldwide. Conservation Biology, 17(6): 1491-1499.

White, P. C., Jennings, N. V., Renwick, A. R., \& Barker, N. H. (2005). Questionnairesin ecology: a review of past use and recommendations for best practice. Journal of Applied Ecology, 42(3): 421-430.

Yoganand, K., Rice, C. G., \& Johnsingh, A. J. (2005). Evaluating Panna National Park with special reference to ecology of Sloth bear (Melursus ursinus). Final Project Report, Wildlife Institute of India.

Yoganand, K., Rice, C. G., Johnsingh, A., \& Seidensticker, J. (2006). Is the sloth bear in India secure? A preliminary report on distribution, threats and conservation requirements. Journal of the Bombay Natural History Society, 103(2-3): 172-181. 